Su, D. Thanh, Nguyen, P. Canh, \& Christophe, S. (2019). Impact of foreign

direct investment, trade openness and economic institutions on growth in

\title{
Impact of foreign direct investment, trade openness and economic institutions on growth in emerging countries: \\ The case of Vietnam
}

\author{
Su Dinh Thanh \\ School of Public Finance, University of Economics Ho Chi Minh City \\ Vietnam \\ Dinbthanb@ueh.edu.vn \\ Nguyen Phuc Canh \\ School of Banking, University of Economics Ho Chi Minh City \\ Vietnam \\ Canbnguyen@ueh.edu.vn \\ Christophe Schinckus \\ Taylor's Business School, Taylor's University \\ Malaysia \\ Christophe.Schinckus@taylors.edu.my
}

Abstract. This article investigates the role of economic institutions and economic openness in the growth of a specific emerging economy - Vietnam. The data from Vietnamese 63 provinces in the period of 2005-2015 have been collected to examine the influences of institutional quality on the inward FDI, trade and growth. By employing the system GMM estimators, our main findings show that, first, the combined effect of inward FDI with trade openness has a substitute effect on the economic growth while they have a positive impact taken separately. This article discusses this interesting aspect. Second, economic institutions significantly influence the combined effects of foreign direct investment with trade openness in improving economic growth.

Keywords: economic institutions, foreign direct investment, growth, trade openness.

JEL Classification: F21, F18, E23, F43

\section{INTRODUCTION}

The role of foreign direct investment (FDI) and trade in promoting economic growth has been studied in literature quite extensively (Samuelson, 1948; Helpman, 1981; Krugman, 1979; Kojima, 1975; Kojima, 1973; Brecher \& Diaz Alejandro, 1977; Bhagwati \& Tironi, 1980). According to the endogenous 
growth theory, trade is argued to have a positive growth effect for emerging countries because it encourages domestic firms to invest in physical capital and technology transfer (Rivera-Batiz \& Romer, 1991, Kim et al., 2016). In the same vein, FDI inflow also has positive spillover effects on a host country due to transfer of technology and management skills coming from developed countries (Borensztein et al., 1998b; de Mello, 1999a; Romer, 1986; Lucas Jr, 1988; Kukeli et al., 2006). Alternatively, Wälde \& Wood (2004) pointed out that the long-run growth effect of trade depends on market configuration and institutional arrangements of each country, and this is also in line with de Mello (1999a) who detailed that the influence of foreign direct investment also depends on institutions and economic scale factors of host countries.

Theoretically, the relationship between FDI and trade may result either from the influence of investment in trade through promotion of export expansion from FDI, or from the impact of trade on investment through establishment of the related services abroad and liberal trade policy regime due to export expansion (Petri't, 1994; Katseli, 1992; Sakyi \& Egyir, 2017). In such a context, the link between these two concepts might still be confusing since it can imply a substitute or a complementary effect. The former effect has been identified by Mundell (1957) who explained how FDI and trade could act as a determinant of production and as a driver for investment. Contrasting with this view, Aizenman and Noy (2006) found that international trade is conditional to the increasing volume of FDI inflow, the very existence of FDI, in turn, has a potential to enhance host country's trade.

The major contribution of this article is in examination of the important role of economic institutions in the combined effect of FDI and trade openness on economic growth. To remind, FDI and trade openness can be perceived as substitute drivers for economic growth since their combined effect on economic growth is negative. Our study uses the main methodology promoted by the mainstream literature on institutions (Kshetri \& Dholakia, 2011; Peev, 2015; Krasniqi \& Desai, 2016; North, 1990; North, 1993). More precisely, we combine economic institutions, FDI and trade openness in a multiple variable analysis (FDI*TRADE*INS). Specifically, high-quality economic institutions (INS_high) reinforce the combined effect of FDI and trade openness on economic growth. In contrast, low-quality economic institutions (INS_low) affect negatively this combined effect of FDI and trade openness on economic growth.

Using the two-step system GMM on a sample of 63 Vietnamese provinces over the period of 20052015, the study has been carried out as follows. First, the study uses trade openness as a proxy for international trade to estimate the link between trade and economic growth. Trade openness level displays the progress of the country's trade structure and its integration into the world trade. The present study will focus on the link between trade openness and economic growth via investment mechanism and productivity growth. Second, we test the direct and combined effects of FDI and trade openness on economic growth. In such a way, this study contributes to literature presenting novel findings from testing the combined effects of institutions with FDI and trade on economic growth. To capture institutional quality, we use the Provincial Competitiveness Index (PCI) as a proxy for provincial economic institutions in line with the previous studies of Dang (2013) and Tran et al. (2009) who showed that improvements in PCI positively influence investment and economic growth of Vietnamese provinces. The present study uses the average level of the whole PCI sample as the criteria to divide total PCI into low PCI level (low institutions) and high PCI level (high institutions). Then, we combine the levels of low institutions and high institutions with foreign direct investment and trade openness to analyze the role of economic institutions. Although our sample covers a particular period (2005-2015) due to the availability of data our empirical findings are expected to highlight the roles of local economic institutions in stimulating local economic growth. It is worth noting that our period of study was very important for Vietnam since the 
country was extending its trade openness and capital liberalization from 2005 while preparing to join the WTO in 2007.

The paper is organized as follows. The next section presents a quick overview of literature on the topic. Section 3 introduces our research model, data, and the econometric approach while section 4 presents the empirical results. Finally, section 5 concludes this study with a discussion of our findings.

\section{LITERATURE REVIEW}

\subsection{The relationship between FDI, trade and economic growth}

FDI and trade are considered as important parts of globalization. Actually, economies that are based on FDI and trade to accelerate growth witnessed a better prosperity of countries in many past decades (Tang et al., 2015). Positive benefits are connected with inward FDI and trade such as poverty reduction, job opportunities, technological transfer, competitiveness, and economic growth (Sakyi \& Egyir, 2017). The relationship between FDI, trade and growth have often been investigated through empirical studies in the context of the export-led growth hypothesis and the FDI-led growth hypothesis. In this perspective, international trade drives its benefits into economic growth by enhancing knowledge diffusion, technological transfer and competitiveness (Eriș \& Ulașan, 2013a, Musila \& Yiheyis, 2015, Trejos \& Barboza, 2015, Fetahi-Vehapi et al., 2015, Ee, 2016, Shahbaz, 2012, Awokuse \& Christopoulos, 2009). Considering industries aspect, Melitz (2000) showed that international trade affects intra-industry allocation and aggregate industry productivity. Within the FDI-led growth hypothesis, inward FDI promotes host countries' economic growth by increasing capital stock, creating jobs, and easing technological transfer (Silajdzic \& Mehic, 2015, Iamsiraroj, 2016, Li \& Liu, 2005, Gohou \& Soumaré, 2012, Yalta, 2013, Almfraji \& Almsafir, 2014, Gui-Diby, 2014, Pham, 2012; Nguyen et al. 2018, 2019). Interestingly, the existing empirical studies testing these hypotheses in emerging countries are still inconsistent. Liu et al. (2002b) showed that there exist co-integration and bidirectional causality among FDI, trade and economic growth in China. While Szkorupová (2014) confirmed the existence of causal links between FDI, exports and economic growth in Slovakia. However, Dritsaki and Stiakakis (2014) found that the link between exports and economic growth is significant whereas inward FDI is an insignificant effect on the economic growth in Croatia. In the same vein, Belloumi (2014) showed that there is no evidence for the existence of bidirectional causality among FDI, trade and growth in Tunisia. Hsiao and Hsiao (2006) examined the relationships between economic growth, exports, and FDI for several Asian countries and they found significant differences in the causal relationships between these variables. In relation to Asian economies, Goh et al. (2017) applied bootstrap test for co-integration to highlight that there does not exist long run co-integration between FDI, exports and growth.

The interpretation of the link between trade and FDI is also a matter of debates: the relationship between these variables is either complementary or substitute. Marchant et al. (2002) found a complementary relationship between FDI and exports in East Asian developing countries. Fontagné (1999) or Wilson and Cacho (2007) also concluded that trade and FDI have a complementary relationship in the OECD countries. Considering the absorptive capacity of countries, Aizenman and Noy (2006) stressed that the link between foreign direct investment and trade is stronger in developing than in developed countries. It is worth noting that a positive relationship between FDI and trade hinges on low trade and financial constraints in developing countries. In contrast, Ponce (2006) found that the relationship between the degree of FDI and trade is inconclusive in Latin America. Countries that signed more free trade treaties increased their potential capacity in attracting FDI inflows. Neary (2009) explained that free trade could lead to dramatic reductions in trade costs and that, therefore, the foreign direct 
investment could grow much faster than trade. Regarding this issue, Pontes (2007) concluded that FDI and trade are complementary in countries with high values of trade costs; however, they might become substitute when values of trade costs are low.

Considering the combined role of FDI and trade on the economic growth, empirical studies have produced mixed and controversial results. Balasubramanyam et al. (1996) emphasized the significant role of FDI in the growth process characterized by various trade regimes in developing countries. Countries, those with outward-oriented trade policies have a stronger positive growth effect of FDI than those with inward-oriented trade policy. Makki (2004) provided evidence that FDI and trade have a positive effect on the economic growth. Interestingly, the growth effect of FDI interacting with trade and domestic investment is positive. Nath (2009a) investigated the relationship between trade, FDI and growth using data for 10 transition economies in Europe. These findings support the hypothesis according to which export-oriented trade policy enhances the growth effect of FDI for these countries. Awan et al. (2012) revealed positive effects of exports and FDI on the economic growth for South Asian countries. Babatunde (2011) highlighted that inward FDI is determined by trade and the income per capita for subSaharan Africa countries in which interaction between trade and infrastructure makes an increase in inward FDI. Sakyi and Egyir (2017) also found that the interaction between FDI and trade enhances the growth effect of both in 45 African countries. Alternatively, some studies show that FDI and trade negatively impact economic growth due to limitations related to country-specific factors such as institutions, trade regime, political risk, human capital and policy (Fortanier, 2007b, de Mello, 1999a, Farshid et al., 2009b, Xu, 2000). Furthermore, Goh et al. (2017) found that the long-run relationship between FDI and trade does not exist in some Asian countries. These results contrast with previous works claiming that the Asian economic miracle mainly depends on an outward-looking strategy implemented by these countries.

Regarding this issue of relationship between FDI and economic growth, Vietnam is a particular emerging economy, where international trade agreements have significantly progressed these recent years. The Vietnamese government has conducted many economic restructuring programs promoting international trade and attracting foreign direct investors in the last two decades (Abbott et al., 2009). This outward-looking strategy has been implemented with the expectation that international trade and FDI could promote economic growth and contribute to the poverty reduction in a context of sustainable developing strategy. However, empirical studies Yang et al. (2015) has remained inconsistent about Vietnam while Xuan and Xing (2008) and Nguyen et al. (2017) showed that FDI contribute to the Vietnam's exports growth and the Vietnam's regions growth; Pham (2012) argued that FDI inflows do not impact exports and imports in long run. In the same vein, Hoang et al. (2010) showed that international trade does not significantly absorb technology and knowledge transfers from FDI inflows to promote economic growth in Vietnam. Such inconclusive evidence suggests that the direct effect of FDI and trade on economic growth requires a further analysis. That is a purpose of this paper.

\subsection{The relationship between FDI, trade and growth: the role of institutions}

Broadly speaking, institutions are defined as "the rule of game" (defined by the government) in a society imposing market rules or constraints on human behaviours (North, 1990; North \& Thomas, 1973). Institutional quality contributes to the reduction of the asymmetric information problem, transactional costs and risks. Hence, institutional quality positively affects the market and resources allocation (Acemoglu and Robinson, 2008, Duncan, 2014, Stefan et al., 2014, Jones and Romer, 2010, Góes and Matheson, 2015). Institutions are also important for improving the relations between human capital, physical factors and economic growth (Jones and Romer, 2010). In emerging countries, a lot of firms 
struggle in their activities and the government can ease the situation by supporting institutions that would promote property rights protection and reduce transaction cost that are key issues for doing business (Kshetri and Dholakia, 2011, Peev, 2015, Krasniqi and Desai, 2016).

Significant effects of institution quality on foreign direct investment and economic performance have been found in various studies (Vadlamannati and Tamazian, 2009, Okada and Samreth, 2014, Asamoah et al., 2016, Buchanan et al., 2012). By using data for 130 countries and regarding the role of corruption as an absorptive capacity (over the period of 1995 - 2008), Okada and Samreth (2014) indicated that the direct effect of FDI on economic growth is insignificant, but the growth effect of foreign direct investment is strengthened when interacting with corruption control. Surprisingly, these results suggest that corruption can be useful by easing business activities in a way that would promote economic growth in these countries. Applying a panel data of 164 countries in the 1996 - 2006 period, Buchanan et al. (2012) showed that institutional quality has a significant role on the FDI volatility in a way that reduces the economic growth. In the same vein, the study of Asamoah et al. (2016) finds that institutional quality is an important factor to stabilize macro-economy and reduce the negative effect of macroeconomic uncertainty on the FDI for 40 countries in the Sub-Saharan African region for the period of $1996-2011$.

Institutions are often presented as a source of comparative advantage affecting positively international trade (Levchenko, 2007). In this context, institutional reforms can increase the economic growth and expand trade flows (Abbott et al., 2009). Considering the influence of institutions combined with trade, Dollar and Kraay (2003) and Azmat and Biman Chand (2008) documented that institutional quality is important for improving trade and growth. Nations with better institutions are likely to trade more and grow faster. The potential determinant of the economic growth is amplified by the combined effect of institutions and trade. For instance, Silberberger and Königer (2016) found that regulatory quality and trade have a significant positive impact on economic growth. Balavac and Pugh (2016) and Mustafa et al. (2017) also observed a positive relationship between trade openness, export diversification and institutional quality of a country. Vietnam has also been studied on this aspect: by applying the Computable General Equilibrium model, Abbott et al. (2009) showed that trade agreements accompanied with institutional reforms improving market access (and domestic investment incentives) positively affected the growth and trade expansion in Vietnam. In addition, Nguyen et al. (2013) provided evidence that sub-national institutions significantly reshape export strategy and firm performance in Vietnam. From the works aforementioned, it is worth noting that none investigated the role of institutions in moderating the growth effects of both FDI and trade in an emerging economy, especially at the province level. To contribute to the literature on links between FDI, trade and growth, we employ multilevel interaction models, including the interaction between FDI and trade; interaction of institutions with FDI and trade to examine the effects of institutional quality on economic growth in 63 Vietnamese provinces.

\section{METHODOLOGY}

\subsection{Research specification}

This study deals with the production function for each Vietnamese province as follows:

$$
Y_{i t}=A_{i t} P R I_{i t}^{\alpha} F D I_{i t}^{\beta} C I N V_{i t}^{\gamma} L I N V_{i t}^{\delta} L T A X_{i t}^{\tau}
$$

where $i$ is for province $(i=1,2,3 \ldots, N)$; t is for time $(t=1,2,3,4 \ldots, T)$. Y is provincial real output per capita. PRI is provincial domestic private investment per capita. FDI is provincial foreign direct investment per capita. LINV is provincial government investment per capita; LTAX is the ratio of provincial tax revenue to the gross provincial product (GPP), which measures the distortionary effect of the tax on provincial 
economic growth as in the study of Jin and Zou (2005). CINV is centre government investment per capita at the national level, which measures the external effect of centre government investment on provincial economic growth as in the study of Nguyen-Van et al. (2018). $\alpha, \beta, \gamma, \delta, \tau$ are assumed not constant returns to calibrate production function.

A is the provincial total factor productivity level. Trade openness (OPEN) positively impacts resource allocation, innovation activity, technological progress and scale economies. Following Dar and AmirKhalkhali (2002), we assume that trade openness has a positive contribution to total factor productivity and then raises the economic growth. Moreover, good economic institutions (INS) enhance effective resource allocation and the productivity growth due to the reduction of asymmetric information and transaction costs. Therefore, we assume that good economic institutions improve the growth of private sector investment and trade openness (Dollar \& Kraay, 2003). A is defined by:

$$
A_{i t}=A_{0} O P E N_{i t}^{\lambda_{1}} e^{\lambda_{2} i n s_{i t}}
$$

Combining Eq. (1) and (2), we have the product function for each province:

$$
Y_{i t}=A_{0} O P E N_{i t}^{\lambda_{1}} e^{\lambda_{2} i n s_{i t}} P R I_{i t}^{\alpha} F D I_{i t}^{\beta} C I N V_{i t}^{\gamma} L I N V_{i t}^{\delta} L T A X_{i t}^{\tau}
$$

Taking the natural logarithm of Eq. (3), we obtain the following output equation:

$$
Y_{i t}=a_{0}+\alpha P R I_{i t}+\beta F D I_{i t}+\gamma C I N V_{i t}+\delta L I N V_{i t}+\tau L T A X_{i t}+\lambda_{1} O P E N_{i t}+\lambda_{2} I N S_{i t}+\epsilon_{i t}
$$

From the general framework of Eq. (4), the following dynamic regression equation is employed to estimate the impact of foreign direct investment and trade openness on economic growth of Vietnam's provinces:

$$
\begin{aligned}
& Y_{i t}=\omega_{0}+\omega_{1} Y_{i t-1}+\omega_{2} P R I_{i t}+\omega_{3} F D I_{i t}+\omega_{4} C I N V_{i t}+\omega_{4} L I N V_{i t}+\omega_{5} L T A X_{i t}+\omega_{6} \text { OPEN }_{i t}+ \\
& \omega_{7} I N S_{i t}+\omega_{8} Z_{i t}+\gamma_{i}+\varepsilon_{i t}
\end{aligned}
$$

where $\mathrm{i}$ is for the province, $\mathrm{t}$ is for the time period, $\gamma$ is a vector of provincial fixed effect specific, $\varepsilon$ is the error term, $\varepsilon_{i t} \sim$ i. i. $d\left(0, \sigma_{\varepsilon}\right.$. Variables in Eq. (5) are calculated as follows:

- $\mathrm{Y}$ is provincial real output per capita, which is calculated through the gross provincial product divided by total provincial employment and adjusted by provincial consumption index.

- PRI is provincial domestic private investment per capita, which is measured through the provincial domestic private investment divided by total provincial employment.

- FDI is provincial foreign direct investment per capita, which is measured through the total provincial foreign direct investment divided by total provincial employment.

- CINV is centre government investment spending divided by total national population

- LINV is provincial government investment spending divided by total provincial employment.

- LTAX is a provincial tax rate, which is measured by total tax revenue divided by gross provincial product.

- OPEN is provincial trade openness, which is measured through the the ratio of total provincial import and export (calculated by annual averaged exchange rate) to the gross provincial product.

- INS is provincial economic institutions, which is proxied by the Provincial Competitiveness Index (PCI).

- $\mathrm{Z}$ is control variable as provincial inflation rate (INF), which is proxied by provincial consumer price index. 


\subsection{Data}

This study uses panel data related to 63 Vietnamese provinces for the period of 2005-2015. These data have been collected from the Vietnam Chamber of Commerce and Industry and the General Statistics Office of Vietnam (GSO). Our time line (2005-2015) directly results from the availability of the data. Precisely, the indicators related to economic institutions (Provincial competiveness index (PCI)) have been collected from VCCI website (https://vcci-hcm.org.vn/home-page/) but unfortunately, these data have not been systematically updated after 2016 making them not consistent for our statistical analysis. In addition to this, our other important data such as Gross provincial product (GPP) per capita, Provincial domestic private investment, Provincial government capital spending per capita, GSO Vietnam are up-todate only until 2015 (see https://www.gso.gov.vn/Default_en.aspx?tabid=491). Data on these aspects have been updated only for large cities such as Ho Chi Minh City or Hanoi. Although our time line is limited to 2005 until 2015, our findings highlight the role of local economic institutions in stimulating economic growth. Another important point, this decade was very important for Vietnam since it corresponds to the period during which the country joined WTO (in 2007).

The table (1) hereafter describes and defines the variables in Eq. (5). We use the Provincial Competitiveness Index (PCI) as a proxy for describing provincial economic institutions. PCI that is offered by the VCCI (Vietnam Chamber of Commerce and Industry) is nowadays identified as a reliable resource in studying the relationship between local institutions and macroeconomics in Vietnam (see Nguyen \& van Dijk, 2012; Dang, 2013; Tran et al., 2009). The overall PCI score is measured by a weighted sum of sub-indices (with a maximum score of 100 points) based on the importance of each subindex in assessing various aspects of firm performance governance in each province.

Table 1

Definitions and descriptive statistics of variables

\begin{tabular}{|c|c|c|c|c|c|c|}
\hline Variables & Definition, description, and source & Obs. & Mean & $\begin{array}{l}\text { Std. } \\
\text { Dev. }\end{array}$ & Min. & Max. \\
\hline $\begin{array}{l}\text { Provincial real } \\
\text { output per } \\
\text { capita (y) }\end{array}$ & $\begin{array}{l}\text { Gross provincial product (GPP) per capita } \\
\text { adjusted by provincial inflation (VND } \\
\text { Million), from GSO of Vietnam }\end{array}$ & 693 & 3862.607 & 8145.356 & 88.075 & 94361.25 \\
\hline $\begin{array}{l}\text { Provincial } \\
\text { private } \\
\text { investment } \\
(P R I)\end{array}$ & $\begin{array}{l}\text { Provincial domestic private investment per } \\
\text { capita adjusted by provincial inflation } \\
\text { (VND Million), from GSO of Vietnam }\end{array}$ & 693 & 88032.05 & 207018.2 & 827.378 & 2425074 \\
\hline $\begin{array}{l}\text { Provincial } \\
\text { foreign direct } \\
\text { investment } \\
(F D I)\end{array}$ & $\begin{array}{l}\text { Provincial foreign direct investment per } \\
\text { capita adjusted by provincial inflation } \\
\text { (VND Million), from GSO of Vietnam }\end{array}$ & 693 & 31082.13 & 81883.65 & 0 & 692941.4 \\
\hline $\begin{array}{l}\text { Central } \\
\text { government } \\
\text { capital } \\
\text { spending } \\
(C I N V)\end{array}$ & $\begin{array}{l}\text { Central government capital spending per } \\
\text { capita at national level (VND Million), from } \\
\text { Key Indicators for Asia and the Pacific } \\
\text { 2017, ADB. }\end{array}$ & 693 & 2058.097 & 738.967 & 966.902 & 3028.425 \\
\hline $\begin{array}{l}\text { Provincial } \\
\text { government } \\
\text { capital } \\
\text { spending } \\
(\text { LINV) }\end{array}$ & $\begin{array}{l}\text { Provincial government capital spending per } \\
\text { capita (VND Million), from GSO of } \\
\text { Vietnam }\end{array}$ & 693 & 56187.93 & 90734.1 & 4521.225 & 967200.2 \\
\hline $\begin{array}{l}\text { Provincial tax } \\
\text { rate }(L T)\end{array}$ & $\begin{array}{l}\text { Provincial government tax revenue to gross } \\
\text { provincial product }(\%) \text {, from GSO of } \\
\text { Vietnam }\end{array}$ & 693 & 2.934 & 1.371 & 0.6427 & 11.750 \\
\hline
\end{tabular}




\begin{tabular}{|l|l|l|l|l|l|l|}
\hline $\begin{array}{l}\text { Economic } \\
\text { institutions } \\
\text { (INS) }\end{array}$ & $\begin{array}{l}\text { Provincial competiveness index (PCI) as } \\
\text { proxy of provincial economic institutions } \\
\text { (\%), from VCCI in Vietnam }\end{array}$ & 671 & 56.981 & 6.143 & 36.39 & 77.2 \\
\hline $\begin{array}{l}\text { Inflation } \\
\text { INF) }\end{array}$ & $\begin{array}{l}\text { Proxied by provincial consumption index, } \\
\text { from GSO of Vietnam }\end{array}$ & $\begin{array}{l}\text { The ratio of total provincial import and } \\
\text { export to gross provincial product (\%), } \\
\text { (Openness } \\
\text { (Olculated by annual averaged exchange } \\
\text { rate, from GSO of Vietnam }\end{array}$ & 110.892 & 13.774 & 90.92 & 242.89 \\
\hline
\end{tabular}

Source: Data statistics are over the period of 2006-2015.

Figure 1 presents the changes in overall PCI core during the period of 2005-2015. It can be observed that the overall PCI core has a convergence trend among Vietnamese provinces. The mean PCI score of the whole sample is 56.981 with values ranging from 36.390 minimum to 77.200 maximum. In line with what we explained above, provinces with a PCI below the mean are ranked into the low institutional quality tier (INS_low), while other provinces are in the high institutional quality tier (INS_ high).

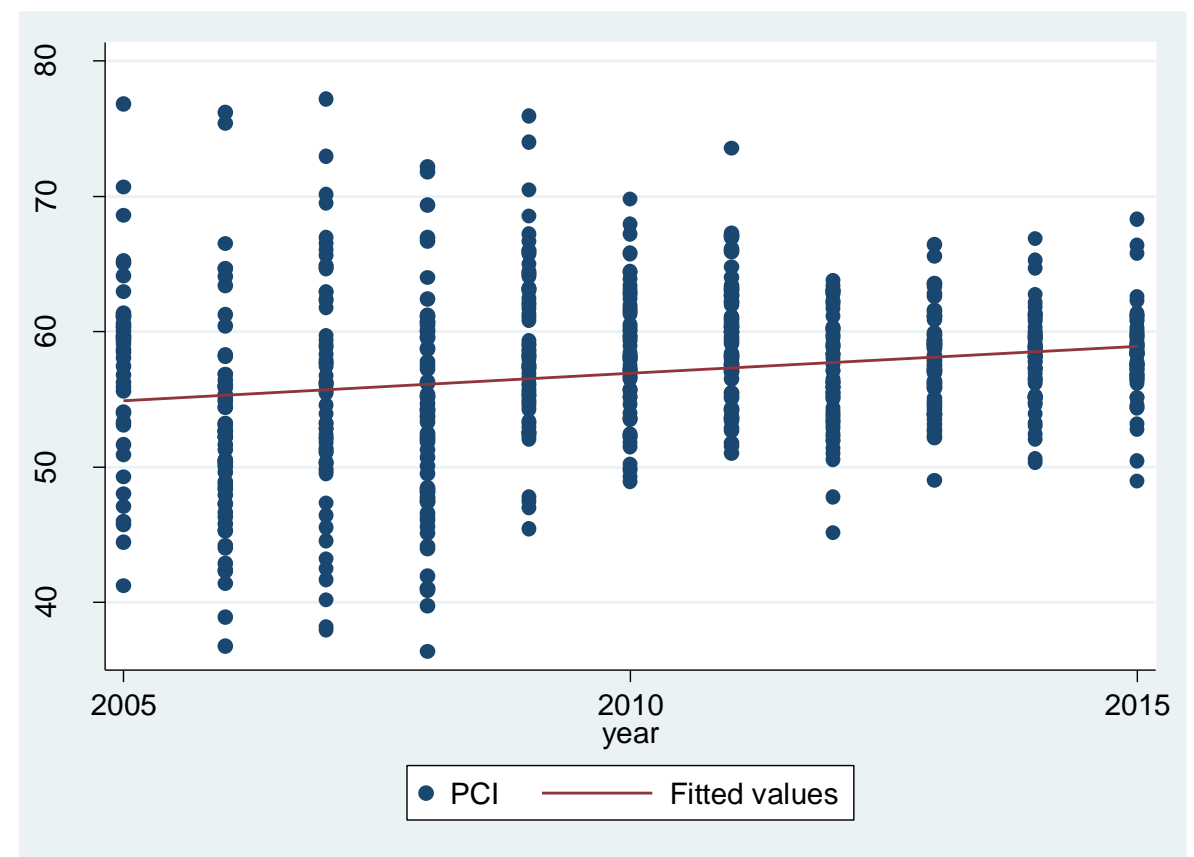

Figure 1. Changes in overall PCI score in Vietnam

Taking the natural logarithm of all variables, we calculate correlation coefficients between variables as presented in Table (2) that shows how the correlation coefficients of all variables are smaller than 0.800 making them appropriate to run a regression. 
Correlation matrix of variables

\begin{tabular}{|c|c|c|c|c|c|c|c|c|c|}
\hline & $\operatorname{Ln}(Y)$ & $\operatorname{Ln}(\mathrm{PRI})$ & $\mathrm{Ln}(\mathrm{FDI})$ & $\mathrm{Ln}(\mathrm{CINV})$ & Ln(LINV) & $\operatorname{Ln}(\mathrm{LTAX})$ & $\mathrm{Ln}(\mathrm{OPEN})$ & INF & $\mathrm{Ln}(\mathrm{PCI})$ \\
\hline $\operatorname{Ln}(Y)$ & 1.000 & & & & & & & & \\
\hline \multirow[t]{2}{*}{$\mathrm{Ln}(\mathrm{PRI})$} & 0.551 & 1.000 & & & & & & & \\
\hline & $0.000^{* * *}$ & & & & & & & & \\
\hline \multirow[t]{2}{*}{$\mathrm{Ln}(\mathrm{FDI})$} & 0.277 & 0.443 & 1.000 & & & & & & \\
\hline & 0.000 & $0.000^{* * *}$ & & & & & & & \\
\hline \multirow{2}{*}{$\mathrm{Ln}(\mathrm{CINV})$} & 0.662 & 0.731 & 0.266 & 1.000 & & & & & \\
\hline & $0.000 * * *$ & $0.000^{* * *}$ & $0.000^{* * *}$ & & & & & & \\
\hline \multirow[t]{2}{*}{ Ln(LINV) } & 0.599 & 0.518 & 0.276 & 0.559 & 1.000 & & & & \\
\hline & $0.000 * * *$ & 0.000 & $0.000 * * *$ & $0.000 * * *$ & & & & & \\
\hline \multirow[t]{2}{*}{$\operatorname{Ln}($ LTAX) } & 0.059 & 0.324 & 0.204 & 0.200 & 0.236 & 1.000 & & & \\
\hline & 0.117 & $0.000^{* * *}$ & $0.000^{* * *}$ & 0.000 & $0.000^{* * *}$ & & & & \\
\hline \multirow[t]{2}{*}{$\mathrm{Ln}(\mathrm{OPEN})$} & 0.100 & $0.374 * * *$ & 0.616 & 0.103 & 0.031 & 0.309 & 1.000 & & \\
\hline & $0.008^{* * *}$ & $0.000^{* * *}$ & $0.000 * * *$ & 0.006 & 0.413 & $0.000^{* * *}$ & & & \\
\hline \multirow[t]{2}{*}{ INF } & -0.226 & -0.037 & $\begin{array}{l}-0.009 \\
\end{array}$ & -0.123 & -0.098 & -0.034 & 0.016 & 1.000 & \\
\hline & $0.000^{* * *}$ & 0.329 & 0.820 & 0.001 & $0.009 * * *$ & 0.358 & 0.662 & & \\
\hline \multirow[t]{2}{*}{$\operatorname{Ln}(\mathrm{PCI})$} & 0.183 & 0.337 & 0.346 & 0.235 & 0.129 & 0.202 & 0.369 & -0.039 & 1.000 \\
\hline & $0.000 * * *$ & $0.000 * * *$ & $0.000 * * *$ & $0.000 * * *$ & $0.008^{* * *}$ & $0.000^{* * *}$ & $0.000^{* * *}$ & 0.309 & \\
\hline
\end{tabular}

Source: Statistics are over the period of 2006-2015. Ln (Y): log of gross provincial nominal product per capita adjusted by inflation. $\operatorname{Ln}(\mathrm{PRI})$ : $\log$ of provincial private investment per capita. $\mathrm{Ln}(\mathrm{FDI}): \log$ of provincial foreigner direct investment per capita. n: provincial population growth rate. $\operatorname{Ln}(\mathrm{CINV}): \log$ of central government capital spending per capita. $\operatorname{Ln}(\operatorname{LINV}): \log$ of provincial government capital spending per capita. LTAX: the ratio of provincial tax revenue to gross provincial product. $\mathrm{Ln}(\mathrm{OPEN})$ : $\log$ of provincial trade openness measured by the ratio of total import and export to gross provincial product. INF: provincial consumption index as a proxy for inflation. $\mathrm{Ln}(\mathrm{PCI})$ : $\log$ of Provincial competiveness index as a proxy for provincial economic institutions. $\left({ }^{*}\right),(* *),(* * *)$ denote significance at level of $1 \%, 5 \%$ and $10 \%$, respectively.

\subsection{Econometric approach}

In the context of a dynamic panel data model with a lagged dependent variable, the estimation of Eq. (5) by fixed effects models implies that regressors might be correlated with the lagged dependent variable. In other words, these coefficients might be seriously biased. In this study, we remove the fixed individual effect because it does not vary with time. Therefore, from Eq. (5), we get $\left(\gamma_{i}-\gamma_{i}\right)+\left(\varepsilon_{i t}-\varepsilon_{i t-1}\right)=$ $\varepsilon_{i t}-\varepsilon_{i t-1}$. In this case, however, the error term would have some lags and therefore will be correlated with the lagged dependent variable, leading to biased estimates. To face with this issue, Arellano and Bond (1991) proposed Generalized Method od of Moments (GMM) method as a technique to deal with endogeneity, heteroscedasticity and serial correlation. This method is specifically designed to capture the joint endogeneity of some explanatory variables through the creation of a weighting matrix of internal instrument, which accounts for serial correlation and heteroscedasticity. GMM estimator technique requires a set of instruments to handle endogeneity and another set to deal with the correlation between lagged-dependent variable and the error term. These instruments include suitable lags of the levels of the endogenous variables and the strictly exogenous regressors. However, a common problem of the Arellano-Bond (1991) is that the variance of the estimates may increase asymptotically and create considerable biases. Blundell and Bond (1998), Blundell et al. (2000) and Soto (2009) showed that the system GMM estimator is likely to present the best features in terms of small sample bias and precision. Notably, as proposed by Kripfganz and Schwarz (2015), we use GMM estimators to eliminate all timeinvariant variables due to a first-difference transformation. Therefore, we apply a sequential (two-stage) estimation to recover fixed effects related to the economic growth. In the first step, we regress Eq. (5) by system GMM estimator. 


$$
Y_{i t}=\beta X_{i t}^{\prime}+\underline{u_{i}}+\varepsilon_{i t} \text { with } \underline{u_{i}}=f_{i}^{\prime}+u_{i}
$$

in which $X_{i t}^{\prime}$ is a vector of explanatory variables as in Eq. (5), $f_{i}^{\prime}$ corresponds to time-invariant variables reflecting provincial fixed characteristics as social-economic geographic factors. In the second step, the coefficients of time-invariant variables are estimated by using a two-step estimation for the residuals from the system GMM estimator.

$$
Y_{i t}-\hat{\beta} X_{i t}^{\prime}=f_{i}^{\prime}+u_{i}+\widehat{\varepsilon_{l t}} \text { with } \widehat{\varepsilon_{l t}}=\varepsilon_{i t}-X_{i t}^{\prime}(\beta-\hat{\beta})
$$

To define time-invariant variables, we select the Mekong River Delta region with high PCI scores as a basic group. Four regional dummies are for the Northern Mountain region (1), the Red River Delta region (2), the Highlands and Central region (3) and the Southeast region (4). For Eq. (6a) and (6b), following up Roodman (2009), we use the p-value of Hansen statistics to test these instruments (Hansen test (1) for Eq. (6a) and Hansen test (2) for Eq. (6b)).

\section{EMPIRICAL RESULTS AND DISCUSSION}

\subsection{Growth effect of foreign direct investment and trade openness}

The results of the estimation for the Eq. (5) are presented in Table (3). Model (1) is estimated by fixed effects. Models (2) and (3) are estimated through Least Squares Dummy Variables while models (4) and (5) are estimated with a two-stage estimation. The interaction between foreign direct investment and trade openness (FDI*OPEN) is put into models (3) and (5). For models (4) and (5), the Arellano-Bond test for autocorrelation has a null hypothesis of no autocorrelation and is applied to differenced residuals. The p-values of the test for $\operatorname{AR}(2)$ show no autocorrelation in all these models. In the same vein, the $\mathrm{p}$ values of Hansen test statistics fail to reject the null hypothesis, implying that our method set appears to be robust.

Table 3

Effects of foreign direct investment and trade openness on provincial economic growth in the period of

\begin{tabular}{|c|c|c|c|c|c|}
\hline \multirow[t]{2}{*}{ VARIABLES } & $\mathrm{FE}$ & \multicolumn{2}{|c|}{ LSDV } & \multicolumn{2}{|c|}{ Sys-GMM } \\
\hline & $(1)$ & (2) & (3) & (4) & (5) \\
\hline \multirow[t]{2}{*}{ Lag of $\log (Y)$} & & & & $0.918^{* * *}$ & $0.921 * * *$ \\
\hline & & & & {$[0.019]$} & {$[0.018]$} \\
\hline \multirow[t]{2}{*}{$\mathrm{Ln}(\mathrm{PRI})$} & $0.331 * * *$ & $0.518^{* * *}$ & $0.524 * * *$ & $0.034 *$ & $0.036^{* *}$ \\
\hline & {$[0.040]$} & {$[0.041]$} & {$[0.040]$} & {$[0.017]$} & [0.016] \\
\hline \multirow[t]{2}{*}{$\mathrm{Ln}(\mathrm{FDI})$} & 0.006 & $0.040^{* * *}$ & $0.050^{* * *}$ & $0.004^{* *}$ & $0.009 * * *$ \\
\hline & {$[0.011]$} & {$[0.012]$} & {$[0.014]$} & {$[0.002]$} & {$[0.002]$} \\
\hline \multirow[t]{2}{*}{$\mathrm{Ln}(\mathrm{CINV})$} & $0.766^{* * *}$ & $0.235^{* * *}$ & $0.230^{* * *}$ & $0.165^{* * *}$ & 0.169 *** \\
\hline & {$[0.087]$} & {$[0.052]$} & {$[0.052]$} & {$[0.026]$} & {$[0.025]$} \\
\hline \multirow[t]{2}{*}{ Ln(LINV) } & $0.161 * * *$ & $0.327 * * *$ & $0.320^{* * *}$ & $0.034 * * *$ & $0.030^{* * *}$ \\
\hline & {$[0.058]$} & {$[0.038]$} & {$[0.037]$} & {$[0.009]$} & {$[0.009]$} \\
\hline \multirow[t]{2}{*}{$\operatorname{Ln}(\operatorname{LTAX})$} & -0.030 & $-0.060 * * *$ & $-0.065^{* * *}$ & 0.005 & 0.002 \\
\hline & {$[0.025]$} & {$[0.016]$} & {$[0.016]$} & {$[0.005]$} & {$[0.004]$} \\
\hline \multirow[t]{2}{*}{$\operatorname{Ln}(\mathrm{OPEN})$} & 0.039 & $0.147 * * *$ & $0.070^{*}$ & $0.020^{* * *}$ & $-0.016^{*}$ \\
\hline & [0.032] & {$[0.019]$} & {$[0.039]$} & {$[0.006]$} & {$[0.009]$} \\
\hline $\operatorname{Ln}(\mathrm{OPEN}) * \operatorname{Ln}(\mathrm{FDI})$ & & & $0.009 * *$ & & $0.004 * * *$ \\
\hline
\end{tabular}
2005-2015, Ln(Y) 


\begin{tabular}{|l|l|l|l|l|l|}
\hline \multirow{2}{*}{ INF } & & & {$[0.004]$} & & {$[0.001]$} \\
\hline \multirow{2}{*}{ Time } & $-0.008^{* * *}$ & $-0.007^{* * *}$ & $-0.007 * * *$ & $-0.001^{* * *}$ & $-0.001^{* * *}$ \\
\hline & {$[0.001]$} & {$[0.001]$} & {$[0.001]$} & {$[0.000]$} & {$[0.000]$} \\
\hline \multirow{2}{*}{ Northern Mountain region } & & & & Yes & yes \\
\cline { 2 - 6 } & & & & -0.095 & -0.088 \\
\hline \multirow{2}{*}{ Highland and Central region } & & & & {$[0.075]$} & {$[0.071]$} \\
\hline & & & & -0.055 & -0.052 \\
\hline \multirow{2}{*}{ Southeast region } & & & & {$[0.087]$} & {$[0.082]$} \\
\hline Constant & & & & 0.037 & 0.035 \\
\hline & & & & {$[0.062]$} & {$[0.059]$} \\
\hline Observations & $-2.436^{* * *}$ & $-2.380^{* * *}$ & $-2.428^{* * *}$ & -0.049 & -0.045 \\
\hline R-squared & {$[0.418]$} & {$[0.383]$} & {$[0.384]$} & $47.322^{* * *}$ & {$[0.056]$} \\
\hline Number of id & 636 & 636 & 636 & $58.815]$ & {$\left[5.640^{* * *}\right.$} \\
\hline Number of instruments & 0.922 & 0.836 & 0.837 & & 581 \\
\hline AR(20 & 63 & 63 & 63 & 63 & 63 \\
\hline Hansen test (1) & & & & 61 & 61 \\
\hline Hansen test (2) & & & & 0.290 & 0.287 \\
\hline Robus in & & & & 0.107 & 0.103 \\
\hline
\end{tabular}

Robust in brackets. ${ }^{* * *} \mathrm{p}<0.01,{ }^{* *} \mathrm{p}<0.05,{ }^{*} \mathrm{p}<0.1$

We can observe a positive influence in the lag of the log of GPP. In line with endogenous growth theory, this observation suggests that the growth trend of Vietnamese provinces results from specialization implying that poor provinces are not likely to catch up the rich ones in long run. The government investment spending positively affects the provincial economic growth, suggesting that the central government investment has an external effect on the Vietnamese province's economic growth as mentioned in the study of Jin and Zou (2005) for China.

Notably, provincial public investment has a positive effect on the economic growth in Vietnamese provinces. This observation is quite surprising since some empirical studies (Van \& Sudhipongpracha, 2015, Nguyen \& Anwar, 2011) on Vietnam's economic growth claimed that the relationship between fiscal policy and economic growth is a generally negative effect finding concerning the role of public investment in the endogenous growth model is interesting. Precisely, the public investment might improve the size and the quality of infrastructures, affecting the productivity growth of the private sector and enhancing economic growth (Felice, 2016). Local tax rate does not create the discretionary effect on provincial economic growth. Furthermore, we observe a positive effect of the domestic private sector investment in accordance with existing empirical studies (Gates (2000), Thi and Ton (2004)). This observation suggests that Vietnam's economic reforms towards market economy have produced a favourable business environment for private sector development generating a rapid economic growth that we observe today in this country. Although the relationship between inflation and the economic growth is still under debate, we also found a significantly negative effect of inflation on the economic growth in line with the empirical study of Jin and Zou (2005) for China.

Our major indicators concerning the growth effects of foreign direct investment (FDI) and trade openness (OPEN) show that both have positive and statistically significant effect on the economic growth (in accordance with existing studies Anwar and Nguyen (2010), Vu (2008), Yang et al. (2015)). It is worth noting that the combined effect of foreign direct investment with trade openness (FDI*OPEN) on the economic growth has a significantly positive sign (see model 5 of Table 3), which is different from studies of Makki (2004), Nath (2009b), Hoang et al. (2010). This result is very interesting when analyzed in terms of marginal growth. Precisely, with the presence of trade openness, the growth effect of FDI is given in 
our estimation by $\frac{\partial y_{i t}}{\partial F D I_{i t}}=0.009+[0.004 * O P E N]$ where trade openness is a continuous variable (with values of trade openness growth between $-6.183(\mathrm{~min})$ and $3.752(\max )$ with an average of -0.877 . This means that the growth effect of foreign direct investment is strengthened when the growth of trade openness is lager that zero.

Our results support the idea that larger trade openness drives more positive externalities generated by foreign direct investment (the diffusion of knowledge, technological spillovers, innovations etc.) into outputs. Such perspective has been suggested by Hoang et al. (2010) who confirmed that smaller international trade openness cannot absorb knowledge transfers coming from foreign direct investment to enhance economic growth.

From another perspective, in the presence of foreign direct investment, the marginal growth effect of trade openness is given in our estimation by $\frac{\partial y_{i t}}{\partial T R A D E_{i t}}=0.016-[0.004 * F D I]$ in which FDI is also a continuous variable with values of foreign direct investment growth between -1.608 (min), and 13.448 $(\max )$ with an average of 8.133. In absence of foreign direct investment, the growth effect of trade is 0.016 while, in presence of foreign direct investment, the marginal growth effect of trade openness has a significant impact. Larger foreign direct investment growth leads to reduced growth effect of trade openness suggesting that there is a substitute effect between foreign direct investment and trade openness. The higher foreign direct investment inflows, the lower the growth effects of trade openness in line with some existing studies on Vietnam (Hoang et al., 2010, Ngoc et al., 2003, Pham, 2012). In other words, our results confirm Pham (2012) who found that foreign direct investment inflows were not associated to the long run growth of exports and imports in Vietnam but also Ngoc et al. (2003) who showed that exports sector has no significant contribution to other economic sector in Vietnam.

\subsection{The role of economic institutions}

This section discusses the influence of economic institutions on the growth effect of foreign direct investment and trade openness. For each Vietnamese province, the provincial competitiveness index (PCI) is used as a proxy for economic institutions with two levels: low institutional quality level (INS low) and high institutional quality level (INS_ high) measured as follow,

if $\mathrm{PCI}<56.981 \%$, INS_low $=1$ and otherwise, INS_low $=0$;

If $56.981 \%,<=$ PCI, INS_high $=1$ and otherwise INS_high $=0$

All observations related to the impact of economic institutions on the economic growth show interesting trends. High-quality of economic institutions has a significantly positive effect on economic growth, whereas a low-quality of economic institutions has a negative influence. We summarize these results in the following Table (4). These results are consistent with the literature emphasizing the that better economic institutions generate a more favourable environment for economic activities implying a reduction of asymmetric information, transactional costs and risks. 
Table 4

Effects of economic institutions on provincial economic growth in the period of 2005-2015, $\operatorname{Ln}(\mathrm{Y})$

\begin{tabular}{|c|c|c|c|c|}
\hline \multirow[t]{2}{*}{ VARIABLES } & \multicolumn{2}{|c|}{ LSDV } & \multicolumn{2}{|c|}{ Sys-GMM } \\
\hline & (1) & (2) & (3) & (4) \\
\hline \multirow[t]{2}{*}{ Lag of $\log (Y)$} & & & 0.909 *** & 0.909 *** \\
\hline & & & [0.019] & [0.019] \\
\hline \multirow[t]{2}{*}{$\mathrm{Ln}(\mathrm{PRI})$} & $0.511 * * *$ & $0.511 * * *$ & $0.033^{*}$ & $0.033^{*}$ \\
\hline & {$[0.040]$} & {$[0.040]$} & {$[0.019]$} & {$[0.019]$} \\
\hline \multirow[t]{2}{*}{$\operatorname{Ln}(\mathrm{FDI})$} & $0.036^{* * *}$ & $0.036^{* * *}$ & $0.003^{*}$ & $0.003^{*}$ \\
\hline & {$[0.012]$} & {$[0.012]$} & {$[0.002]$} & {$[0.002]$} \\
\hline \multirow[t]{2}{*}{$\operatorname{Ln}(\mathrm{CINV})$} & $0.226^{* * *}$ & $0.226 * * *$ & $0.154 * * *$ & $0.154 * * *$ \\
\hline & {$[0.050]$} & {$[0.050]$} & {$[0.026]$} & {$[0.026]$} \\
\hline \multirow[t]{2}{*}{ Ln(LINV) } & $0.326^{* * *}$ & $0.326^{* * *}$ & $0.038^{* * *}$ & $0.038^{* * *}$ \\
\hline & {$[0.037]$} & {$[0.037]$} & {$[0.011]$} & {$[0.011]$} \\
\hline \multirow[t]{2}{*}{$\operatorname{Ln}(\operatorname{LTAX})$} & $-0.061 * * *$ & $-0.061 * * *$ & 0.004 & 0.004 \\
\hline & {$[0.015]$} & [0.015] & {$[0.004]$} & {$[0.004]$} \\
\hline \multirow{2}{*}{$\operatorname{Ln}(\mathrm{OPEN})$} & $0.137^{* * *}$ & $0.137 * * *$ & $0.017^{* *}$ & $0.017 * *$ \\
\hline & [0.019] & {$[0.019]$} & {$[0.007]$} & {$[0.007]$} \\
\hline \multirow[t]{2}{*}{ INS_low } & $-0.138^{* * *}$ & & $-0.056^{*}$ & \\
\hline & {$[0.034]$} & & {$[0.029]$} & \\
\hline \multirow[t]{2}{*}{ INS_high } & & $0.138^{* * *}$ & & $0.056^{*}$ \\
\hline & & {$[0.034]$} & & {$[0.029]$} \\
\hline \multirow[t]{2}{*}{ INF } & $-0.007 * * *$ & $-0.007 * * *$ & $-0.001 * * *$ & $-0.001 * * *$ \\
\hline & {$[0.001]$} & {$[0.001]$} & {$[0.000]$} & {$[0.000]$} \\
\hline Time & & & Yes & Yes \\
\hline \multirow{2}{*}{ Northern Mountain region } & & & -0.101 & -0.101 \\
\hline & & & {$[0.074]$} & {$[0.074]$} \\
\hline \multirow{2}{*}{ Red River Delta region } & & & -0.059 & -0.059 \\
\hline & & & {$[0.088]$} & {$[0.088]$} \\
\hline \multirow[t]{2}{*}{ Highland and Central region } & & & 0.031 & 0.031 \\
\hline & & & {$[0.063]$} & {$[0.063]$} \\
\hline \multirow[t]{2}{*}{ Southeast region } & & & -0.054 & -0.054 \\
\hline & & & {$[0.059]$} & {$[0.059]$} \\
\hline \multirow[t]{2}{*}{ Constant } & $-2.160 * * *$ & $-2.298^{* * *}$ & $47.039^{* * *}$ & $46.983^{* * *}$ \\
\hline & {$[0.376]$} & {$[0.376]$} & [5.731] & [5.733] \\
\hline Observations & 636 & 636 & 581 & 581 \\
\hline R-squared & 0.840 & 0.840 & & \\
\hline Number of id & 63 & 63 & 63 & 63 \\
\hline Number of instruments & & & 61 & 61 \\
\hline $\operatorname{AR}(2)$ & & & 0.291 & 0.291 \\
\hline Hansen test (1) & & & 0.122 & 0.122 \\
\hline Hansen test (2) & & & 0.765 & 0.765 \\
\hline
\end{tabular}

Robust in brackets. ${ }^{* * *} \mathrm{p}<0.01,{ }^{* *} \mathrm{p}<0.05, * \mathrm{p}<0.1$

To know how the various levels of economic institutions quality improve the effects of foreign direct investment and trade openness on economic growth, we generate dummy variables for the interaction terms for the following variables FDI*INS low, FDI*INS_high, OPEN*INS_low, OPEN*INS_high, and FDI*OPEN*INS_low, and FDI*OPEN*INS_high. As in Table (5), models (1) and (2) are estimated for FDI*INS_low and FDI*INS_high. Models (3) and (4) are for OPEN*INS_low and OPEN*INS_high. And, models (5) and (6) are for FDI*OPEN*INS_low and FDI*OPEN*INS_high. 
Table 5

Effects of interacting foreign direct investment and trade openness with economic institutions on provincial economic growth in the period of 2005-2015, $\mathrm{Ln}(\mathrm{Y})$

\begin{tabular}{|c|c|c|c|c|c|c|}
\hline \multirow[t]{2}{*}{ VARIABLES } & \multicolumn{6}{|c|}{ Sys_GMM } \\
\hline & (1) & (2) & (3) & (4) & (5) & (6) \\
\hline \multirow[t]{2}{*}{ Lag of $\log (Y)$} & $0.909 * * *$ & $0.909 * * *$ & $0.909 * * *$ & $0.909 * * *$ & $0.907 * * *$ & $0.909 * * *$ \\
\hline & {$[0.019]$} & {$[0.019]$} & [0.019] & [0.019] & {$[0.020]$} & {$[0.021]$} \\
\hline \multirow{2}{*}{ Ln(PRI) } & $0.033^{*}$ & $0.033^{*}$ & $0.033^{*}$ & $0.033^{*}$ & $0.049^{* * *}$ & $0.049 * *$ \\
\hline & [0.019] & [0.019] & [0.019] & [0.019] & [0.019] & [0.019] \\
\hline \multirow[t]{2}{*}{$\operatorname{Ln}(\mathrm{FDI})$} & $0.003^{*}$ & $0.003^{*}$ & $0.003^{*}$ & $0.003^{*}$ & $0.009 * * *$ & $0.009^{* * *}$ \\
\hline & {$[0.002]$} & {$[0.002]$} & {$[0.002]$} & {$[0.002]$} & {$[0.003]$} & {$[0.003]$} \\
\hline \multirow[t]{2}{*}{$\mathrm{Ln}(\mathrm{CINV})$} & $0.154^{* * *}$ & $0.154^{* * *}$ & $0.154^{* * *}$ & $0.154^{* * *}$ & $0.158^{* * *}$ & $0.160^{* * *}$ \\
\hline & {$[0.026]$} & {$[0.026]$} & {$[0.026]$} & {$[0.026]$} & {$[0.027]$} & {$[0.028]$} \\
\hline \multirow[t]{2}{*}{$\overline{\operatorname{Ln}(\mathrm{LINV})}$} & $0.038^{* * *}$ & $0.038^{* * *}$ & $0.038^{* * *}$ & $0.038^{* * *}$ & $0.027^{* * *}$ & $0.027 * * *$ \\
\hline & {$[0.011]$} & {$[0.011]$} & {$[0.011]$} & {$[0.011]$} & {$[0.008]$} & {$[0.008]$} \\
\hline \multirow[t]{2}{*}{ Ln(LTAX) } & 0.004 & 0.004 & 0.004 & 0.004 & 0.003 & 0.002 \\
\hline & {$[0.004]$} & {$[0.004]$} & {$[0.004]$} & {$[0.004]$} & {$[0.004]$} & {$[0.004]$} \\
\hline \multirow[t]{2}{*}{$\operatorname{Ln}(\mathrm{OPEN})$} & $0.017^{* *}$ & $0.017^{* *}$ & $0.017 * *$ & $0.017^{* *}$ & $-0.027 * *$ & $-0.026 * *$ \\
\hline & {$[0.007]$} & {$[0.007]$} & {$[0.007]$} & {$[0.007]$} & {$[0.012]$} & {$[0.012]$} \\
\hline \multirow[t]{2}{*}{ Ln(FDI)*INS_low (Dummy) } & $-0.057^{\prime}$ & & & & & \\
\hline & {$[0.030]$} & & & & & \\
\hline \multirow[t]{2}{*}{ Ln(FDI)*INS_high (Dummy) } & & $0.056^{*}$ & & & & \\
\hline & & {$[0.029]$} & & & & \\
\hline \multirow[t]{2}{*}{ Ln(OPEN)*INS_low (Dummy) } & & & $-0.057 *$ & & & \\
\hline & & & {$[0.030]$} & & & \\
\hline \multirow{2}{*}{ Ln(OPEN)*INS_high (Dummy) } & & & & $0.057^{*}$ & & \\
\hline & & & & {$[0.030]$} & & \\
\hline \multirow[t]{2}{*}{$\operatorname{Ln}(\mathrm{FDI}) * \operatorname{Ln}(\mathrm{OPEN})$} & & & & & $0.005^{* * *}$ & $0.005^{* * *}$ \\
\hline & & & & & {$[0.001]$} & {$[0.001]$} \\
\hline \multirow[t]{2}{*}{ Ln(FDI)*Ln(OPEN)*INS_low (Dummy) } & & & & & $-0.049 * *$ & \\
\hline & & & & & {$[0.022]$} & \\
\hline \multirow[t]{2}{*}{ Ln(FDI)*Ln(OPEN)*INS_high (Dummy) } & & & & & & $0.043^{*}$ \\
\hline & & & & & & {$[0.023]$} \\
\hline \multirow[b]{2}{*}{ INF } & $-0.001 * * *$ & $-0.001 * * *$ & $-0.001 * * *$ & $-0.001 * * *$ & $-0.001 * * *$ & $-0.001 * * *$ \\
\hline & {$[0.000]$} & {$[0.000]$} & {$[0.000]$} & {$[0.000]$} & {$[0.000]$} & {$[0.000]$} \\
\hline Time & yes & yes & yes & yes & yes & yes \\
\hline \multirow[t]{2}{*}{ Northern Mountain region } & -0.101 & -0.101 & -0.101 & -0.101 & -0.013 & -0.013 \\
\hline & {$[0.074]$} & {$[0.074]$} & {$[0.074]$} & {$[0.074]$} & {$[0.024]$} & {$[0.024]$} \\
\hline \multirow[t]{2}{*}{ Red River Delta region } & -0.058 & -0.059 & -0.058 & -0.058 & -0.014 & -0.015 \\
\hline & {$[0.088]$} & {$[0.088]$} & {$[0.088]$} & {$[0.088]$} & {$[0.049]$} & {$[0.049]$} \\
\hline \multirow[t]{2}{*}{ Highland and Central region } & 0.031 & 0.031 & 0.031 & 0.031 & 0.027 & 0.028 \\
\hline & {$[0.063]$} & {$[0.063]$} & {$[0.063]$} & {$[0.063]$} & {$[0.026]$} & {$[0.027]$} \\
\hline \multirow[t]{2}{*}{ Southeast region } & -0.053 & -0.054 & -0.053 & -0.053 & 0.002 & 0.003 \\
\hline & {$[0.059]$} & [0.059] & {$[0.059]$} & {$[0.059]$} & {$[0.018]$} & {$[0.017]$} \\
\hline Constant & $47.072^{* * *}$ & $46.983^{* * *}$ & $47.072^{* * *}$ & $47.015^{* * *}$ & $50.564 * * *$ & $50.794 * * *$ \\
\hline & {$[5.738]$} & [5.733] & {$[5.738]$} & {$[5.740]$} & {$[5.546]$} & {$[5.674]$} \\
\hline Observations & 581 & 581 & 581 & 581 & 581 & 581 \\
\hline Number of id & 63 & 63 & 63 & 63 & 63 & 63 \\
\hline Number of instruments & 61 & 61 & 61 & 61 & 61 & 61 \\
\hline $\mathrm{AR}(2)$ & 0.291 & 0.291 & 0.291 & 0.291 & 0.289 & 0.290 \\
\hline Hansen test (1) & 0.123 & 0.122 & 0.123 & 0.123 & 0.105 & 0.101 \\
\hline Hansen test (2) & 0.762 & 0.765 & 0.762 & 0.762 & 0.985 & 0.985 \\
\hline
\end{tabular}

Robust in brackets

*** $\mathrm{p}<0.01,{ }^{* *} \mathrm{p}<0.05,{ }^{*} \mathrm{p}<0.1$

Our observations show expected results. More specifically, the effect of FDI*INS low on growth is negative while the effect of FDI*INS_high is positive (see models $1 \& 2$ in Table 5). In other words, these observations highlight that the important role of economic institutions in enhancing the effect of FDI on the economic growth (in line with existing studies for developing countries Vadlamannati and Tamazian, 
2009, Okada and Samreth, 2014, Asamoah et al., 2016, Buchanan et al., 2012). Similarly, by combining trade openness with economic institutions, the result is further confirmed since the combined term between low-quality economic institutions and trade openness (OPEN*INS_low) has a negative effect on the economic growth whereas the interaction between high-quality economic institutions and trade openness (OPEN*INS_high) has a positive effect (see Models 3\&4 in Table 5). Our results provide significantly empirical evidence that, for any improvements in economic institutions, the growth effects of trade are also improved. These observations show that improvements in economic institutions can support economic growth via a reinforcement of the combined effect of FDI and trade openness. Alternatively, these results illustrate that if the government does not improve economic institutions, FDI and trade openness can adversely affect economic growth.

\subsection{Check robustness}

In this part, we implement robustness test for links between FDI, trade, economic institutions and economic growth. The sample data is restructured by calculating the mean for the 5 -year period. We conducted LSDV estimations and present, in Table (6), the results of robustness tests are consistent with the main results in Tables (3)-(5).

Table 6

Check robustness by LSDV estimate for averaged 5 years

\begin{tabular}{|c|c|c|c|c|c|c|c|c|c|c|}
\hline VARIABLES & \multicolumn{10}{|c|}{ LSDV estimate for averaged 5 years } \\
\hline \multirow[t]{2}{*}{ Ln(PRI) } & $0.541^{* * *}$ & $0.521^{* * *}$ & $0.521 * * *$ & $0.522^{* * *}$ & $0.521 * * *$ & $0.521 * * *$ & $0.524 * * *$ & $0.551 * * *$ & $0.522^{* * * *}$ & $0.524^{* * * *}$ \\
\hline & {$[0.083]$} & {$[0.083]$} & {$[0.083]$} & {$[0.083]$} & {$[0.083]$} & {$[0.083]$} & {$[0.082]$} & {$[0.083]$} & {$[0.083]$} & {$[0.082]$} \\
\hline Ln(FDI) & $0.044^{* *}$ & $0.039^{*}$ & $0.039^{*}$ & $0.039 *$ & $0.039^{*}$ & $0.039 *$ & 0.039 * & $0.052^{* *}$ & $0.040^{*}$ & $0.039 *$ \\
\hline \multirow[t]{2}{*}{$\operatorname{Ln}(\mathrm{CINV})$} & $0.269 * *$ & $0.244 * *$ & $0.244 * *$ & $0.244^{* *}$ & $0.245^{* * *}$ & $0.247 * *$ & $0.242 * *$ & $0.256^{* * *}$ & $0.246 * *$ & $0.242^{* *}$ \\
\hline & {$[0.113]$} & {$[0.107]$} & {$[0.107]$} & {$[0.107]$} & {$[0.107]$} & {$[0.108]$} & {$[0.107]$} & {$[0.115]$} & {$[0.108]$} & {$[0.107]$} \\
\hline \multirow[t]{2}{*}{$\begin{array}{l}\operatorname{Ln}(\operatorname{LINV}) \\
\end{array}$} & $0.323^{* * *}$ & $0.314^{* * * *}$ & $0.314^{* * *}$ & $0.314^{* * * *}$ & $0.314^{* * *}$ & $0.313^{* * * *}$ & $0.314^{* * * *}$ & $0.316^{* * * *}$ & $0.313^{* * * *}$ & $0.314 * * *$ \\
\hline & {$[0.074]$} & {$[0.071]$} & {$[0.071]$} & {$[0.072]$} & {$[0.071]$} & {$[0.071]$} & {$[0.072]$} & {$[0.074]$} & {$[0.071]$} & {$[0.072]$} \\
\hline \multirow[t]{2}{*}{$\operatorname{Ln}(\mathrm{OPEN})$} & $0.119^{* * *}$ & $0.104^{* * *}$ & $0.104 * * *$ & $0.104^{* * * *}$ & $0.103^{* * * *}$ & $0.104 * * *$ & $0.104 * * *$ & 0.056 & $0.104^{* * * *}$ & $0.104 * * *$ \\
\hline & {$[0.031]$} & {$[0.030]$} & {$[0.030]$} & {$[0.030]$} & {$[0.030]$} & {$[0.030]$} & {$[0.030]$} & {$[0.053]$} & {$[0.030]$} & {$[0.030]$} \\
\hline \multirow[t]{2}{*}{ INF } & $-0.006 * * *$ & $-0.006 * * *$ & $-0.006^{* * * *}$ & $-0.006 * * *$ & $-0.006 * * *$ & $-0.006 * * *$ & $-0.006 * * *$ & $-0.006 * * *$ & $-0.006 * * *$ & $-0.006 * * *$ \\
\hline & {$[0.002]$} & {$[0.001]$} & {$[0.001]$} & {$[0.001]$} & {$[0.001]$} & {$[0.001]$} & {$[0.001]$} & {$[0.002]$} & {$[0.001]$} & {$[0,001]$} \\
\hline \multirow[t]{2}{*}{ INS_low } & & $-0.253^{* * *}$ & & & & & & & & \\
\hline & & {$[0.078]$} & & & & & & & & \\
\hline INS_high & & & $0.253^{* * * *}$ & & & & & & & \\
\hline \multirow{2}{*}{ Ln(FDI)*INS_low (Dummy) } & & & & & & $-0.247^{* * * *}$ & & & & \\
\hline & & & & & & {$[0.078]$} & & & & \\
\hline \multirow[t]{2}{*}{ Ln(FDI)*INS_high (Dummy) } & & & & & & & $0.254^{* * *}$ & & & \\
\hline & & & & & & & {$[0.077]$} & & & \\
\hline \multirow[t]{2}{*}{$\operatorname{Ln}(\mathrm{FDI}) * \operatorname{Ln}(\mathrm{OPEN})$} & & & & & & & & 0.007 & & \\
\hline & & & & & & & & {$[0.005]$} & & \\
\hline \multirow[t]{2}{*}{ Ln(FDI)*Ln(OPEN)*INS_low (Dummy) } & & & & & & & & & $-0.242 * * *$ & \\
\hline & & & & & & & & & {$[0.078]$} & \\
\hline \multirow{2}{*}{ Ln(FDI)*Ln(OPEN)*INS_high (Dummy) } & & & & & & & & & & $0.256^{* * * *}$ \\
\hline & & & & & & & & & & {$[0.077]$} \\
\hline \multirow[t]{2}{*}{ Constant } & $-3.019 * * *$ & $-2.393 * * *$ & $-2.646 * * *$ & $-2.395^{* * * *}$ & $-2.649 * * *$ & $-2.405^{* * * *}$ & $-2.660^{* * * *}$ & $-3.037 * * *$ & $-2.407 * * *$ & $-2.662^{* * * *}$ \\
\hline & {$[0.770]$} & {$[0.751]$} & {$[0.743]$} & {$[0.753]$} & {$[0.742]$} & {$[0.752]$} & {$[0.743]$} & {$[0.771]$} & {$[0.753]$} & {$[0.743]$} \\
\hline Observations & 182 & 182 & 182 & 182 & 182 & 182 & 182 & 182 & 182 & 182 \\
\hline $\mathrm{R}$-squared & 0.863 & 0.869 & 0.869 & 0.869 & 0.869 & 0.869 & 0.869 & 0.864 & 0.868 & 0.869 \\
\hline
\end{tabular}

The next section will discuss and conclude our empirical studies. 


\section{DISCUSSION}

Methodologically speaking, our study employs the GMM estimators to deal with endogeneity, heteroscedasticity and serial correction and to show that FDI and trade openness have significant effects on the economic growth in Vietnamese Province. However, the combined effect of FDI and trade openness on the economic growth is negative, suggesting that FDI and trade openness act as substitute drivers for growth in Vietnam. Precisely, FDI can boost the productivity growth of the host country and then enhance exports. However, FDI and trade openness can be substitute or complement because the effect of FDI on trade depends on several perspectives such as comparative advantage, technological and industrial development of the host country Kojima (1975), Sun (1999), Borensztein et al. (1998a). On the road to international economic integration, Vietnam's export-oriented industrialization strategy helped much to increase FDI attraction and expand international trade. However, some potential flaws behind this strategy need to be fixed: FDI inflows indeed did not necessary increase employment and labour productivity (Jenkins, 2006) and these FDI inflows mainly targeted manufacturing sector leading to an industrial bias in production, trade and investment policies (Athukorala and Tien, 2012, SchaumburgMüller, 2003). In addition, technology spillovers from FDI are still limited because business links and knowledge transfers between foreign sectors and domestic sectors are still weak. In this context, Vietnam's exports competition capacity needs time to improve and this situation leads Vietnam to apply new production technology and innovations in its export (Nguyen et al., 2008).

Another important contribution of this paper refers to the importance of economic institutions for the Vietnam's economic internationalization. In this article, we used the Provincial Competitiveness Index as a proxy for economic institutions composed by sub-indices: entry cost for new firms, land access, policy transparency, time costs of regulatory compliance, informal charges, pro-activity of provincial leadership, policy bias, labour training, and legal institutions. These sub-indices are reflected the capacity of local economic governance, but also the progress in local public administration reforms (Dang, 2013). The impact of economic institutions on the economic growth is significantly positive because they reduce the asymmetric information problem, transactional costs and risks. More interestingly, economic institutions are found to play an important role in driving the combined effects of FDI and trade openness to a better economic growth. These findings are the most notable contribution. As aforementioned, the growth effect of FDI and trade openness is conditionally related to other factors. Since the late 1990s, many studies have investigated the combination of institutions with FDI and trade openness to seek significant change in economic growth. This combination appears to be a determinant for growth since the institutional quality improves the positive effects of FDI and trade openness on the economic activity (Bénassy-Quéré et al., 2007, Dollar and Kraay, 2003, Buchanan et al., 2012). Finally, in relation with economic institutions, the combined effects of FDI with trade on growth are stronger in confidence interval of $95 \%$ than the combined effects of trade with FDI (see Figure 5\&6). These results confirm that FDI is very sensitive to the quality of economic institutions in line with Buchanan et al. (2012). We observed that a better institutional quality can lead to an increase in trade in Vietnam, but this effect is relatively divergent. This might be due to the fact that changes in institutions need much time to be in effect of trade (Abbott et al., 2009). The study by Dollar and Kraay (2003) also indicated that the combination of institutions and trade improving is important to understand differences between countries in long-run growth. 


\section{CONCLUSION}

This paper investigates the impact of FDI and trade openness on the economic growth. Such influence has been investigated in several steps. After having studied the individual and combined effect of these variables, we investigated further their combined effect with the quality of economic institutions. Due to the availability of data, our study worked with a sample of 63 Vietnamese provinces in the period of 2005-2015. Although this period covers only one decade, our findings provide interesting observations on the roles played by local institutions in the economic growth in context in which Vietnam started to open its economy to join WTO in 2007. Our main findings show that, first, the combined effect of inward FDI with trade openness has a substitute effect on the economic growth while they have a positive impact taken separately. This article discusses and illustrates this interesting aspect. Second, economic institutions significantly influence the combined effects of foreign direct investment with trade openness in improving economic growth These findings are helpful to design macroeconomic policies in dealing with the relationship between economic institutions, FDI and trade. Our results invite policy makers to consider a holistic strategy in terms of economic growth. A proper policy integrating economic and institutional considerations is required to ensure a long-term profitable economic growth.

\section{ACKNOWLEDGEMENT}

The author(s) disclosed receipt of the following financial support for the research of this article: The author acknowledges to have received funding from the University of Economics Ho Chi Minh City, Vietnam.

\section{REFERENCES}

Abbott, P., Bentzen, J. \& Tarp, F. (2009). Trade and Development: Lessons from Vietnam's Past Trade Agreements. World Development, 37 (1), 341-353.

Acaravci, A. \& Ozturk, I. (2012). Foreign Direct Investment, Export and Economic Growth: Empirical Evidence from New Eu Countries. Romanian Journal of Economic Forecasting, 2(2), 52-67.

Acemoglu, D. \& Robinson, J. (2008). The Role of Institutions in Growth and Development. World Bank, Washington Dc.

Aizenman, J. \& Noy, I. (2006). Fdi and Trade - Two-Way Linkages? The Quarterly Review of Economics and Finance, 46(3), 317-337.

Ali, F. A., Fiess, N. \& Macdonald, R. (2010). Do Institutions Matter for Foreign Direct Investment? Open Economies Review, 21(1), 201-219.

Almfraji, M. A. \& Almsafir, M. K. (2014). Foreign Direct Investment and Economic Growth Literature Review from 1994 to 2012. Procedia-Social and Behavioral Sciences, 129(2), 206-213.

Anwar, S. \& Nguyen, L. P. (2010). Foreign Direct Investment and Economic Growth in Vietnam. Asia Pacific Business Review, 16(1), 183-202.

Arellano, M. \& Bond, S. (1991). Some Tests of Specification for Panel Data: Monte Carlo Evidence and an Application to Employment Equations. Review of Economic Study, 3(2), 277 - 297.

Asamoah, M. E., Adjasi, C. K. D. \& Alhassan, A. L. (2016). Macroeconomic Uncertainty, Foreign Direct Investment and Institutional Quality: Evidence from Sub-Saharan Africa. Economic Systems, 40(12), 612-621.

Athukorala, P.-C. \& Tien, T. Q. (2012). Foreign Direct Investment in Industrial Transition: the Experience of Vietnam. Journal of the Asia Pacific Economy, 17(2), 446-463.

Atique, Z., Ahmad, M. H., Azhar, U. \& Khan, A. H. (2004). The Impact of Fdi on Economic Growth under Foreign Trade Regimes: A Case Study of Pakistan [With Comments]. The Pakistan Development Review, 43(4), 707-718.

Awan, R. U., Javed, K. \& Sher, F. (2012). Foreign Direct Investment, Economic Growth, Trade and Domestic Investment Relationship: an Econometric Analysis of Selected South Asian Countries. Interdisciplinary Journal of Contemporary Research in Business, 3(1), 32-44.

Awokuse, T. O. \& Christopoulos, D. K. (2009). Nonlinear Dynamics and the Exports-Output Growth Nexus. Economic Modelling, 26(2), 184-190. 
Azmat, G. \& Biman Chand, P. (2008). The Relationship Between Institutional Quality and Trade in Pacific Island Countries. Journal of International Trade Law and Policy, 7(2), 123-138.

Babatunde, A. (2011). Trade Openness, Infrastructure, Fdi and Growth in Sub-Saharan African Countries. Journal of Management Policy and Practice, 12(5), 27-36.

Balasubramanyam, V. N., M, S. \& D, S. 1996. Foreign Direct Investment and Growth in Ep and Is Countries. the Economic Journal, 106(3), 92-105.

Balavac, M. \& Pugh, G. (2016). The Link between Trade Openness, Export Diversification, Institutions and Output Volatility in Transition Countries. Economic Systems, 40(3), 273-287.

Belloumi, M. (2014). The Relationship between Trade, Fdi and Economic Growth in Tunisia: an Application of the Autoregressive Distributed Lag Model. Economic Systems, 38(2), 269-287.

Bénassy-Quéré, A., Coupet, M. \& Mayer, T. (2007). Institutional Determinants of Foreign Direct Investment. the World Economy, 30, 764-782.

Beverelli, C., Fiorini, M. \& Hoekman, B. (2017). Services Trade Policy and Manufacturing Productivity: the Role of Institutions. Journal of International Economics, 104(7), 166-182.

Bhagwati, J. N. \& Tironi, E. (1980). Tariff Change, Foreign Capital and Immiserization. Journal of Development Economics, 7(2), 71-83.

Blundell, R. \& Bond, S. (1998). Initial Conditions and Moment Restrictions in Dynamic Panel Data Models. Journal of Econometrics, 87(4), 115-143.

Blundell, R., Bond, S. \& Windmeijer, F. (2000). Estimation in Dynamic Panel Data Models: Improving on the Performance of the Standard Gmm Estimator. Advances in Econometrics. Jai Press, Elsevier Science, Amsterdam, 15(1), 2-8.

Borensztein, E., De Gregorio, J. \& Lee, J. W. (1998). How Does Foreign Direct Investment Affect Economic Growth?1. Journal of International Economics, 45(8), 115-135.

Brecher, R. A. \& Diaz Alejandro, C. F. (1977). Tariffs, Foreign Capital and Immiserizing Growth. Journal of International Economics, 7, 317-322.

Buchanan, B. G., Le, Q. V. \& Rishi, M. (2012). Foreign Direct Investment and Institutional Quality: Some Empirical Evidence. International Review of Financial Analysis, 21(3), 81-89.

Chand, S., Duncan, R. \& Quang, D. (2001). The Role of Institutions in the Development of Vietnam. Asean Economic Bulletin, 18, 276-288.

Cieślik, A. \& Tarsalewska, M. (2008). Trade, Foreign Direct Investment and Economic Growth: Empirical Evidence for Cee Countries. Warsaw University, Department of Economics, Macroeconomics and International Trade Theory Division.

Dang, D. A. (2013). How Foreign Direct Investment Promote Institutional Quality: Evidence from Vietnam. Journal of Comparative Economics, 41(9), 1054-1072.

Dar, A. A. \& Amirkhalkhali, S. (2002). Government Size, Factor Accumulation, and Economic Growth: Evidence from Oecd Countries. Journal of Policy Modeling, 24(4), 679-692.

De Mello, J. L. R. (1999a). Foreign Direct Investment-Led Growth: Evidence from Time Series and Panel Data. Oxford Economic Papers, 51(3), 133-151.

De Mello, L. R. (1999b). Foreign Direct Investment-Led Growth: Evidence from Time Series and Panel Data. Oxford Economic Papers, 51(3), 133-151.

Dollar, D. \& Kraay, A. (2003). Institutions, Trade, and Growth. Journal of Monetary Economics, 50(1), 133-162.

Dritsaki, C. \& Stiakakis, E. (2014). Foreign Direct Investments, Exports, and Economic Growth in Croatia: A Time Series Analysis. Procedia Economics and Finance, 14(3), 181-190.

Duncan, R. (2014). Institutional Quality, the Cyclicality of Monetary Policy and Macroeconomic Volatility. Journal of Macroeconomics, 39(2), Part A, 113-155.

Ee, C. Y. (2016). Export-Led Growth Hypothesis: Empirical Evidence from Selected Sub-Saharan African Countries. Procedia Economics and Finance, 35(2), 232-240.

Eriș, M. N. \& Ulașan, B. (2013a). Trade Openness and Economic Growth: Bayesian Model Averaging Estimate of Cross-Country Growth Regressions. Economic Modelling, 33(8), 867-883.

Farshid, P., Ali, S. \& Gholamhosein, S. (2009a). The Impact of Foreign Direct Investment and Trade on Economic Growth-Taking China, Korea, Malaysia, Philippines \& Thailand for Example. China-USA Business Review, $8(2), 37-43$

Farshid, P., Ali, S. \& Gholamhosein, S. (2009b). The Impact of Foreign Direct Investment and Trade on Economic Growth-Taking China, Korea, Malaysia, Philippines \& Thailand for example. China-USA Business Review, 8(2), 3-13.

Felice, G. (2016). Size and Composition of Public Investment, Sectoral Composition and Growth. European Journal of Political Economy, 44(10), 136-158. 
Fetahi-Vehapi, M., Sadiku, L. \& Petkovski, M. (2015). Empirical Analysis of the Effects of Trade Openness on Economic Growth: an Evidence for South East European Countries. Procedia Economics and Finance, 19(2), $17-26$.

Fontagné, L. (1999). Foreign Direct Investment and International Trade: Complements or Substitutes? Oecd Science, Technology and Industry Working Papers, 1999/03.

Fortanier, F. (2007a). Foreign Direct Investment and Host Country Economic Growth: Does the Investor's Country of Origin Play a Role. Transnational Corporations, 16 (3), 41-76.

Fortanier, F. (2007b). Foreign Direct Investment and Host Country Economic Growth: Does the Investor's Country of Origin Play a Role? Transnational Corporations, 16 (3), 23-33.

Gates, C. L. (2000). Vietnam's Economic Transformation and Convergence with the Dynamic Asean Economies. Comparative Economic Studies, 42(5), 7-43.

Ghironi, F. \& Melits, M. J. (2005). International Trade and Macroeconomic Dynamics with Heterogeneous Firms. The Quarterly Journal of Economics, 120(12), 865-915.

Góes, C. \& Matheson, T. 2015. Domestic Market Integration and the Law of One Price in Brazil. Imf Working Paper Wp/15/21

Góes, C. \& Matheson, T. (2017). Domestic Market Integration and the Law of One Price in Brazil. Applied Economics Letters, 24(1), 284-288.

Goh, S. K., Sam, C. Y. \& Mcnown, R. (2017). Re-Examining Foreign Direct Investment, Exports, and Economic Growth in Asian Economies Using A Bootstrap Ardl Test for Cointegration. Journal of Asian Economics, $51(4), 12-22$.

Gohou, G. \& Soumaré, I. (2012). Does Foreign Direct Investment Reduce Poverty in Africa and Are There Regional Differences? World Development, 40(8), 75-95.

Gueorguiev, D. \& Malesky, E. (2012). Foreign Investment and Bribery: A Firm-Level Analysis of Corruption in Vietnam. Journal of Asian Economics, 23(7), 111-129.

Gui-Diby, S. L. (2014). Impact of Foreign Direct Investments on Economic Growth in Africa: Evidence from Three Decades of Panel Data Analyses. Research in Economics, 68(4), 248-256.

Helpman, E. (1981). International Trade in the Presence of Product Differentiation, Economies of Scale and Monopolistic Competition: A Chamberlin-Heckscher-Ohlin Approach. Journal of International Economics, 11(7), 305-340.

Hoang, T. T., Wiboonchutikula, P. \& Tubtimtong, B. (2010). Does Foreign Direct Investment Promote Economic Growth in Vietnam? Asean Economic Bulletin, 27(9), 295-311.

Hsiao, F. S. T. \& Hsiao, M.-C. W. (2006). Fdi, Exports, and Gdp in East and Southeast Asia-Panel Data versus Time-Series Causality Analyses. Journal of Asian Economics, 17(2), 1082-1106.

Huchet-Bourdon, M., Le Mouël, C. \& Vijil, M. (2018). The Relationship between Trade Openness and Economic Growth: Some New Insights on the Openness Measurement Issue. The World Economy, 41(4), 59-76.

Iamsiraroj, S. (2016). The Foreign Direct Investment-Economic Growth Nexus. International Review of Economics \& Finance, 42(3), 116-133.

Jenkins, R. (2006). Globalization, Fdi and Employment in Viet Nam. Transnational Corporations, 15(3), 115.

Jin, J. \& Zou, H.-F. (2005). Fiscal Decentralization, Revenue and Expenditure Assignments, and Growth in China. Journal of Asian Economics, 16, 1047-1064.

Jones, C. I. \& Romer, P. M. (2010). The New Kaldor Facts: Ideas, Institutions, Population, and Human Capital. American Economic Journal: Macroeconomics, 2(4), 224-45.

Katseli, L. T. (1992). Foreign Direct Investment and Trade Interlinkages in the 1990s: Experience and Prospects of Developing Countries. Cepr Discussion Papers.

Keho, Y. (2017). The Impact of Trade Openness on Economic Growth: the Case of Cote D'ivoire. Cogent Economics \& Finance, 5(3), 1332820.

Kim, D.-H., Lin, S.-C. \& Suen, Y.-B. (2016). Trade, Growth and Growth Volatility: New Panel Evidence. International Review of Economics \& Finance, 45(3), 384-399.

Kojima, K. (1973). A Macroeconomic Approach to Foreign Direct Investment. Hitotsubashi Journal of Economics, 14, 121.

Kojima, K. (1975). International Trade and Foreign Investment: Substitutes or Complements. Hitotsubashi Journal of Economics, 16, 1-12.

Krasniqi, B. A. \& Desai, S. (2016). Institutional Drivers of High-Growth Firms: Country-Level Evidence from 26 Transition Economies. Small Business Economics, 1-20.

Kripfganz, S. \& Schwarz, C. (2015). Estimation of Linear Dynamic Panel Data Models with Time-Invariant Regressors. Ecb Working Paper No. 1838.

Krugman, P. R. (1979). Increasing Returns, Monopolistic Competition, and International Trade. Journal of International Economics, 9(2), 469-479. 
Kshetri, N. \& Dholakia, N. (2011). Regulative Institutions Supporting Entrepreneurship in Emerging Economies: A Comparison of China and India. Journal of International Entrepreneurship, 9(2), 110-132.

Kukeli, A., Fan, C.-M. \& Fan, L.-S. (2006). Fdi and Growth in Transition Economies: Does the Mode of Transition Make A Difference? Rivista Internazionale Di Scienze Economiche E Commerciali, 53(2), 302-322.

Levchenko, A. A. (2007). Institutional Quality and International Trade. The Review of Economic Studies, 74(2), 791-819.

Li, X. \& Liu, X. (2005). Foreign Direct Investment and Economic Growth: an Increasingly Endogenous Relationship. World Development, 33(1), 393-407.

Liu, X., Burridge, P. \& Sinclair, P. J. (2002). Relationships between Economic Growth, Foreign Direct Investment and Trade: Evidence from China. Applied Economics, 34(5), 1433-1440.

Lucas Jr, R. E. (1988). On the Mechanics of Economic Development. Journal of Monetary Economics, 22(4), 3-42.

Makki, S. S. \& Somwaru, A. (2004). Impact of Foreign Direct Investment and Trade on Economic Growth: Evidence from Developing Countries. American Journal of Agricultural Economics, 86(8), 795-801.

Marchant, M. A., Cornell, D. N. \& Koo, W. (2002). International Trade and Foreign Direct Investment: Substitutes or Complements. Journal of Agricultural and Applied Economics, 34(6), 289-302.

Martin, M. F. (2016). U.S. - Vietnam Economic and Trade Relations: Issues for the 114th Congress. Congressional Research Service Report (Www.Crs.Gov), 7-5700.

Melitz, M. (2000). International Trade and Industry Productivity Dynamics with Heterogeneous Producers. University of Michigan (Phd). Retrieved $17 \quad$ November 2018 from Https://Search.Proquest.Com/Docview/304607604.

Meyer, K. E. \& Nguyen, H. V. (2005). Foreign Investment Strategies and Sub-National Institutions in Emerging Markets: Evidence from Vietnam. Journal of Management Studies, 42(3), 63-93.

Mundell, R. A. (1957). International Trade and Factor Mobility. American Economic Review, 47(8), 321-335.

Musila, J. W. \& Yiheyis, Z. (2015). The Impact of Trade Openness on Growth: the Case of Kenya. Journal of Policy Modeling, 37(8), 342-354.

Mustafa, G., Rizov, M. \& Kernohan, D. (2017). Growth, Human Development, and Trade: the Asian Experience. Economic Modelling, 61(8), 93-101.

Nath, H. K. (2009). Trade, Foreign Direct Investment, and Growth: Evidence from Transition Economies. Comparative Economic Studies, 51(5), 20-50.

Neary, J. P. (2009). Trade Costs and Foreign Direct Investment. International Review of Economics \& Finance, 18(7), $207-$ 218.

Ngoc, P. M., Anh, N. T. P. \& Nga, P. T. (2003). Exports and Long-Run Growth in Vietnam, 1975\&\#X2013; 2001. Asean Economic Bulletin, 20, 211-232.

Nguyen-Van, P., Pham, T. K. C. \& Le, D.-A. (2018). Productivity and Public Expenditure: A Structural Estimation for Vietnam's Provinces. Asia-Pacific Journal of Regional Science, 23(5), 282-200.

Nguyen, A. N. \& Nguyen, T. (2007). Foreign Direct Investment in Vietnam: an Overview and Analysis the Determinants of Spatial Distribution across Provinces.

Nguyen, A. N., Pham, N. Q., Nguyen, C. D. \& Nguyen, N. D. (2008) Innovation and Exports in Vietnam's Sme Sector. The European Journal of Development Research, 20(7), 262-280.

Nguyen, D. T. H., Sun, S. \& Anwar, S. (2017). A Long-Run and Short-Run Analysis of the Macroeconomic Interrelationships in Vietnam. Economic Analysis and Policy, 54(4), 15-25.

Nguyen, L. P. \& Anwar, S. (2011). Fiscal Decentralisation and Economic Growth in Vietnam. Journal of the Asia Pacific Economy, 16(4), 3-14.

Nguyen, T. T. \& Van Dijk, M. A. (2012). Corruption, Growth, and Governance: Private vs. State-Owned Firms in Vietnam. Journal of Banking \& Finance, 36(23), 2935-2948.

Nguyen, T. V., Le, N. T. B. \& Bryant, S. E. (2013). Sub-National Institutions, Firm Strategies, and Firm Performance: A Multilevel Study of Private Manufacturing Firms in Vietnam. Journal of World Business, 48(9), 68-76.

Nguyen C.P., Su D.T, Schinckus C. \& Chong F.H.L (2018), Institutions, Inward Foreign Direct Investment, Trade Openness and Credit Level in Emerging Economies, Review of Development Finance, 8 (2), 75-88.

Nguyen C.P., Su D.T, Schinckus C. \& Chong F.H.L (2019), the Influence of Foreign Direct Investment on Productivity: an Institutional Perspective. The Journal of Economics Finance and Administrative Science. Forthcoming

North, D. C. (1990). Institutions, Institutional Change and Economic Performance, Cambridge University Press.

North, D. C. (1993). Institutional Change: A Framework of Analysis. Institutional Change: Theory and Empirical Findings, 35-46.

Okada, K. \& Samreth, S. (2014). How Does Corruption Influence the Effect of Foreign Direct Investment on Economic Growth? Global Economic Review, 43(6), 207-220. 
Peev, E. (2015). Institutions, Economic Liberalization and Firm Growth: Evidence from European Transition Economies. European Journal of Law and Economics, 40(2), 149-174.

Petri't, P. A. (1994). The Regional Clustering of Foreign Direct Investment and Trade. Retrived July, 16, 2015, from Www. Unctad.Org/En/Docs/Iteiitv3n3a2_En.Pdf.

Pham, T. H. H. (2012). Temporal Causality and the Dynamics of Foreign Direct Investment and Trade in Vietnam. The Journal of International Trade \& Economic Development, 21(5), 83-113.

Ponce, A. F. (2006). Openness and Foreign Direct Investment: the Role of Free Trade Agreements in Latin America. Mpra Paper, 8858.

Pontes, J. P. (2007). A Non-Monotonic Relationship between Fdi and Trade. Economics Letters, 95(14), $369-373$.

Rivera-Batiz, L. A. \& Romer, P. M. (1991). International Trade with Endogenous Technological Change. European Economic Review, 35(2), 971-1001.

Romer, P. M. (1986). Increasing Returns and Long-Run Growth. Journal of Political Economy, 94(3), 1002-1037.

Roodman, D. (2009). A Note on the Theme of Too Many Instruments. Oxford Bulletin of Economics and Statistics, 71(3), 135-158.

Sakyi, D., Commodore, R. \& Opoku, E. E. O. (2015). Foreign Direct Investment, Trade Openness and Economic Growth in Ghana: an Empirical Investigation. Journal of African Business, 16(9), 1-15.

Sakyi, D. \& Egyir, J. (2017). Effects of Trade and Fdi on Economic Growth in Africa: an Empirical Investigation. Transnational Corporations Review, 9(5), 66-87.

Samuelson, P. A. (1948). International Trade and the Equalisation of Factor Prices. The Economic Journal, 58(6), 163184.

Schaumburg-Müller, H. (2003). Rise and fall of Foreign Direct Investment in Vietnam and Its Impact on Local Manufacturing Upgrading. The European Journal of Development Research, 15(4), 44-66.

Schmidt, U. (2004). Vietnam's Integration into the Global Economy. Achievements and Challenges. Asia Europe Journal, 2(1), 63-83.

Shahbaz, M. (2012). Does Trade Openness Affect Long Run Growth? Cointegration, Causality and Forecast Error Variance Decomposition Tests for Pakistan. Economic Modelling, 29(4), 2325-2339.

Silajdzic, S. \& Mehic, E. (2015). Knowledge Spillovers, Absorptive Capacities and the Impact of Fdi on Economic Growth: Empirical Evidence from Transition Economies. Procedia - Social and Behavioral Sciences, 195(33), 614-623.

Silberberger, M. \& Königer, J. (2016). Regulation, Trade and Economic Growth. Economic Systems, 40(5), 308-322.

Soto, M. (2009). System Gmm Estimation with A Small Sample. Barcelona Economics Working Paper Series, No 395.

Stefan, D., Comes, C.-A., Munteanu, A., Nistor, P., Stefan, A.-B. \& Talmaciu, M. (2014). Emerging Markets Queries in Finance and Business (Emq 2013) Study on the Relationships between Institutions, Governance and Leadership and Regional Development Policy in Romania. Procedia Economics and Finance, 15, 1281-1288.

Sun, H. (1999). Impact of Fdi on the Foreign Trade of China. Journal of the Asia Pacific Economy, 4(4), 317-339.

Szkorupová, Z. (2014). A Causal Relationship between Foreign Direct Investment, Economic Growth and Export for Slovakia. Procedia Economics and Finance, 15(4), 123-128.

Tahir, M. \& Khan, I. (2014). Trade Openness and Economic Growth in the Asian Region. Journal of Chinese Economic and Foreign Trade Studies, 7(12), 136-152.

Tang, C. F., Lai, Y. W. \& Ozturk, I. (2015). How Stable Is the Export-Led Growth Hypothesis? Evidence from Asia's Four Little Dragons. Economic Modelling, 44(9), 229-235.

Tarp, F., Roland-Holst, D. \& Rand, J. (2002). Trade and Income Growth in Vietnam: Estimates from a New Social Accounting Matrix. Economic Systems Research, 14(5), 157-184.

Thi, D. T. \& Ton, L. D. (2004). Vietnam's Economy: Achievements and Perspective. International Journal of Asian Management, 3(3), 67-75.

Tran, T. B., Grafton, R. Q. \& Kompas, T. (2009). Institutions Matter: the Case of Vietnam. The Journal of SocioEconomics, 38)4), 1-12.

Trejos, S. \& Barboza, G. (2015). Dynamic Estimation of the Relationship between Trade Openness and Output Growth in Asia. Journal of Asian Economics, 36, 110-125.

Undp (2009). Institutional Reform for Public Administration in Contemporary Viet Nam. United Nations Development Programme ( Www.Undp.Org.Vn).

Vadlamannati, K. C. \& Tamazian, A. (2009). Growth Effects of Fdi in 80 Developing Economies: the Role of Policy Reforms and Institutional Constraints. Journal of Economic Policy Reform, 12(7), 299-322.

Van, V. B. \& Sudhipongpracha, T. (2015). Exploring Government Budget Deficit and Economic Growth: Evidence from Vietnam's Economic Miracle. Asian Affairs: an American Review, 42(3), 127-148. 
Vasakui, T., Thai, L. V. \& Van, L. T. P. (2009). Public Administration and Economic Development in Vietnam: Reforming the Public Administration for the 21st Century. Reference Book: Reforming Public Administration in Viet Nam: Current Situation and Recommendations (Undp in Vietnam).

Vu, T. B. (2008). Foreign Direct Investment and Endogenous Growth in Vietnam. Applied Economics, 40(4), 11651173.

Vu, T. B., Gangnes, B. \& Noy, I. (2008). Is Foreign Direct Investment Good for Growth? Evidence from Sectoral Analysis of China and Vietnam. Journal of the Asia Pacific Economy, 13(1), 542-562.

Wälde, K. \& Wood, C. (2004). The Empirics of Trade and Growth: Where Are the Policy Recommendations? International Economics and Economic Policy, 1(2), 275-292.

Were, M. (2015). Differential Effects of Trade on Economic Growth and Investment: A Cross-Country Empirical Investigation. Journal of African Trade, 2(2), 71-85.

Wilson, N. \& Cacho, J. (2007). Linkage Between Foreign Direct Investment, Trade and Trade Policy: an Economic Analysis With Application To the Food Sector in Oecd Countries and Case Studies in Ghana, Mozambique, Tunisia and Uganda, Oecd Trade Policy Papers, No. 50, Oecd Publishing.

Xu, B. (2000). Multinational Enterprises, Technology Diffusion, and Host Country Productivity Growth. Journal of Development Economics, 62(1), 477-493.

Xuan, N. T. \& Xing, Y. 2008. Foreign Direct Investment and Exports the Experiences of Vietnam1. Economics of Transition, 16, 183-197.

Yalta, A. Y. (2013). Revisiting the Fdi-Led Growth Hypothesis: the Case of China. Economic Modelling, 31(2), 335-343.

Yang, C.-H., Ramstetter, E. D., Tsaur, J.-R. \& Ngoc Phan, M. (2015). Openness, Ownership, and Regional Economic Growth in Vietnam. Emerging Markets Finance and Trade, 51 (2), S224-S233.

Zelekha, Y. \& Sharabi, E. (2012). Corruption, Institutions and Trade. Economics of Governance, 13(1), 169-192. 